\title{
HIPOGLIKEMIA PADA PASIEN DIABETES MELITUS
}

\author{
Mesa Sukmadani Rusdi ${ }^{*}$ \\ 1 Program Studi Farmasi, Universitas Dharma Andalas, \\ Jl. Sawahan No 103A, Simpang Haru, Padang, Sumatera Barat \\ * Penulis Korespondensi. Email: mesarusdi09@gmail.com
}

\begin{abstract}
ABSTRAK
Diabetes melitus (DM) adalah penyakit gangguan metabolik yang ditandai oleh kenaikan glukosa darah akibat penurunan sekresi insulin oleh sel beta pankreas dan atau resistensi insulin. Hipoglikemia merupakan salah satu risiko mayor yang sering diderita pasien DM. Hipoglikemia merupakan efek samping yang paling umum dari penggunaan insulin dan sulfonilurea terkait mekanisme aksi dari obat tersebut. Hipoglikemia ditemukan sebagai barier utama dalam mencapai kepuasan jangka panjang kontrol glikemik dan menjadi komplikasi yang ditakuti dari terapi DM Komplikasi akut dan kronis dari hipoglikemia dapat mengganggu kehidupan, seperti interaksi sosial, tidur, aktivitas seks, mengemudi, olahraga, dan aktivitas lainnya. Monitoring glukosa darah perlu dilakukan untuk mencegah risiko hipoglikemia. Pasien yang diterapi dengan insulin, sulfonilurea/ glinid dianjurkan untuk mengecek glukosa darah kapanpun merasa adanya gejala hipoglikemia.
\end{abstract}

Kata Kunci:

Hipoglikemia, Diabetes Melitus, edukasi

$\begin{array}{lcc}\text { Diterima: } & \text { Disetujui: } & \text { Online: } \\ \text { 23-02-2020 } & 2-07-2020 & 1-09-2020\end{array}$

\section{ABSTRACT}

Diabetes mellitus (DM) is a metabolic disorder characterized by an increase in insulin due to decreased insulin secretion by pancreatic beta cells and/or insulin resistance. Hypoglycemia is one of the main risks that DM patients often to suffer. in Type 2 DM, hypoglycemia is the most common side effect of the use of insulin and sulfonylureas. It is because of their modes of action . Hypoglycaemia presents a major barrier to satisfactory long term glycemic control and remains a feared complication of diabetes treatment. Acute and chronic complications of hypoglycemia can interfere with life, such as social interactions, sleep, sexual activity, driving, sports, and other activities. Blood glucose monitoring needs to be done to prevent the risk of hypoglycemia. Patients treated with insulin, sulfonylureas/glinides are advised to check blood glucose any time hypoglycemia is going to happen.

Copyright (C) 2020 Jsscr. All rights reserved.

Keywords:

Hypoglycemia, Diabetes Mellitus, education

\begin{tabular}{ccc}
\hline Received: & Accepted: & Online: \\
2020-02-23 & $2020-07-2$ & $2020-09-1$ \\
\hline
\end{tabular}

\section{Pendahuluain}

Diabetes melitus (DM) adalah penyakit gangguan metabolik yang ditandai oleh kenaikan glukosa darah akibat penurunan sekresi insulin oleh sel beta pankreas dan atau ganguan/ resistensi insulin [1]. Risiko utama yang biasa ditemukan pada setiap penderita yang didiagnosis penyakit DM diantanya hipoglikemia 
hiperglikemia, ketoasidosis diabetik, dehidrasi dan trombosis. Hipoglikemia dan hiperglikemia merupakan risiko mayor yang sering diderita pasien DM [2].

Hipoglikemia dapat dialami oleh semua pasien DM, di mana pasien DM tipe 1 lebih sering mengalami hipoglikemia dibandingkan dengan pasien DM tipe 2. Tidak seperti diabetik nefropati dan diabetik retinopati yang merupakan manifestasi kronis penyakit DM, hipoglikemia dapat terjadi secara akut, tiba- tiba dan dapat mengancam nyawa [3]. Maka dari itu, diperlukan pengetahuan tentang hipoglikemia, baik terhadap pencegahan, terapi dan monitoring yang harus diperhatikan jika terjadi hipoglikemia.

\section{Hasil dan Pembahasan}

\subsection{Hipoglikemia}

Hipoglikemia merupakan suatu keadaan penurunan konsentrasi glukosa serum dengan atau tanpa adanya gejala sistem autonom dan neuroglikopenia. Hipoglikemia ditandai dengan menurunnya kadar glukosa darah $<70$ mg/dl $(<4,0$ mmol/L) dengan atau adanya whipple's triad, yaitu terdapat gejala-gejala hipoglikemia, seperti kadar glukosa darah yang rendah, gejala berkurang dengan pengobatan. Hipoglikemia sering dialami oleh pasien DM tipe 1, diikuti oleh pasien DM tipe 2 yang diterapi dengan insulin dan sulfonilurea $[4,5,6]$.

Hipoglikemia merupakan efek samping yang paling umum dari penggunaan insulin dan sulfonilurea pada terapi DM, terkait mekanisme aksi dari obat tersebut, yaitu mencegah kenaikan glukosa darah daripada menurunkan konsentrasi glukosa. Metformin, pioglitazone, inhibitor DPP- 4, acarbose, inhibitor SLGT-2 and analog GLP-1 yang diresepkan tanpa insulin atau insulin sekretagog (sulfonylurea/ glinide) jarang menyebabkan hipoglikemia. Hipoglikemia ditemukan sebagai hambatan utama dalam mencapai kepuasan jangka panjang kontrol glikemik dan menjadi komplikasi yang ditakuti dari terapi DM [7].

Kurangnya asupan makanan diketahui merupakan salah satu faktor risiko terjadinya hipoglikemia. Hipoglikemia diperkirakan menjadi penyebab kematian pada $2-4 \%$ pasien DM tipe 1 . Walaupun kontribusi hipoglikemia sebagai penyebab kematian pada DM tipe 2 masih belum jelas, tidak jarang dugaan hipoglikemia menjadi penyebab kematian. Angka kejadian hipoglikemia pada pasien DM tipe 2 beberapa kali lipat lebih rendah dibandingkan DM tipe 1 [2]. Risiko hipoglikemia yang berat dikaitkan dengan penggunaan insulin atau sulfonilurea dan glinid, perubahan dosis obat, dan perubahan gaya/aktivitas hidup yang terlalu drastis. 


\subsection{Gejala Hipoglikemia}

Gejala dan tanda hipoglikemia tidaklah spesifik antar individu. Hipoglikemia dapat ditegakkan dengan adanya Whipple's Triad. Gejala hipoglikemia dikategorikan menjadi neuroglikopenia, yaitu gejala yang berhubungan langsung terhadap otak apabila terjadi kekurangan glukosa darah. Otak sangat bergantung terhadap suplai yang berkelanjutan dari glukosa darah sebagai bahan bakar metabolisme dan support kognitif. Jika level glukosa darah menurun maka disfungsi kognitif tidak bisa terelakkan. Gejala hipoglikemia kedua, adalah autonom, yaitu gejala yang terjadi sebagai akibat dari aktivasi sistem simpato-adrenal sehingga terjadi perubahan persepsi fisiologi [8,9]. Menurut PERKENI [4] dan Yale et al [5], gejala dan tanda hipoglikemia adalah sebagai berikut:

Tabel 1. Gejala dan tanda Hipoglikemia

Tanda

Gejala

\begin{tabular}{ll}
\hline Autonom & $\begin{array}{l}\text { Gemetar, palpitasi, berkeringat, Pucat, takikardia, widened } \\
\text { gelisah, lapar, mual, kesemutan pulse pressure } \\
\text { paresthesia, palpitasi, } \\
\text { Tremulousness }\end{array}$ \\
\hline neuroglikopenia & Kesulitan konsentrasi, bingung, Lemah, Cortical-blindness, \\
& lesu, dizziness, Pandangan kabur, pusing, hipotermia, kejang, koma \\
& perubahan sikap, gangguan kognitif, \\
& pandangan kabur, diplopia
\end{tabular}

\subsection{Faktor Risiko Hipoglikemia pada DM}

Hipoglikemia terjadi jarena ketidakseimbangan antara suplai glukosa, pengunaan glukosa dan level insulin [7]. Faktor risiko kejadian hipoglikemia pada pasien DM sering berkaitan dengan penggunaan insulin atau insulin sekretagog (sulfonilurea/glinid) yang kurang tepat, diantaranya [8]:

1. Dosis insulin dan insulin sekretagog (sulfonilurea/glinid) yang berlebihan, salah aturan pakai atau salah jenis insulin.

2. Intake glukosa berkurang, bisa disebabkan oleh lupa makan atau puasa

3. Penggunaan glukosa yang meningkat (pada saat dan sehabis olahraga)

4. Produksi glukosa endogen berkurang (pada saat konsumsi alkohol)

5. Sensitivitas insulin meningkat (pada saat tengah malam, berat badan turun, kesehatan membaik dan pada saat peningkatan kontrol glikemik)

6. Penurunan bersihan insulin (pada kasus gagal ginjal)

\subsection{Keparahan Hipoglikemia}

Menurut Yale et al [5] dan Paluchamy [10], tingkat keparahan hipoglikemia pada pasien DM dikategorikan sebagai berikut : 
Tabel 2. Tingkat keparahan hipoglikemia

Ringan Rentang glukosa darah adalah $54-70 \mathrm{mg} / \mathrm{dl}$. Terdapat gejala autonom, yaitu tremor, palpitasi, gugup, takikardi, berkeringat, dan rasa lapar. Pasien dapat mengobati sendiri.

Sedang Rentang glukosa darah adalah $40-54 \mathrm{mg} /$ dl.Terdapat gejala autonom dan neuroglikopenia, seperti bingung, rasa marah, kesulitan konsenterasi, sakit kepala, lupa, mati rasa pada bibir dan lidah, kesulitan bicara, mengantuk dan pandangan kabur. Pasien dapat mengobati sendiri.

Berat Glukosa darah kurang dari $40 \mathrm{mg} / \mathrm{dl}$. Terjadi kerusakan sistem saraf pusat, dengan gejala perubahan emosi, kejang, stupor, atau penurunan kesadaran. Pasien membutuhkan bantuan orang lain untuk pemberian karbohidrat, glukagon, atau resusitasi lainnya. Bisa terjadi ketidaksadaran pasien.

\subsection{Manajemen Hipoglikemia}

Tujuan terapi hipoglikemia adalah mengembalikan dengan cepat level glukosa darah ke rentang normal, mengurangi atau meniadakan risiko injuri dan gejala. Namun, terapi hipoglikemia harus memperhatikan dan menghindari overtreatment yang bisa menjadikan pasien hiperglikemia dan peningkatan berat badan. Ketika diperlukan, pengukuran glukosa darah dilakukan untuk mengkonfirmasi adanya hipoglikemia (khususnya ketika terdapat kemungkinan pasien tersebut dalam pengaruh alkohol) $[5,8]$.

\subsubsection{Pencegahan Hipoglikemia}

Hipoglikemia pada pasien DM dapat dicegah, apabila pasien sadar terhadap kemungkinan terjadinya hipoglikemia. Pencegahan Hipoglikemia membutuhkan pendekatan yang terintegrasi [11]. Menurut PERKENI[4], Yale et al [5] dan Brown dan Abdelhafiz [12], langkah - langkah yang bisa dilakukan agar terhindar dari kejadian hipoglikemia adalah, sebagai berikut:

1. Lakukan edukasi mengenai tanda dan gejala hipoglikemia

2. Hindari farmakoterapi yang bisa meningkatkan risiko kambuh atau hipoglikemia berat

3. Tingkatkan Pemantauan Glukosa Darah Mandiri (PGDM), khususnya bagi pengguna insulin atau obat oral golongan sekretagog; termasuk pada jam tidur

4. Lakukan edukasi tentang obat - obat atau insulin yang dikonsumsi, tentang dosis, waktu mengkonsumsi, dan efek samping

\subsubsection{Terapi Hipoglikemia Ringan - Sedang}

Terapi yang bisa diberikan pada hipoglikemia ringan- sedang adalah

1. Pemberian makanan tinggi glukosa (karbohidrat) [5]

2. Ketika terapi hipoglikemia, pilihan karbohidrat menjadi penting.

3. Karbohidrat kompleks atau makanan yang mengandung lemak bersamaan dengan karbohidrat (seperti coklat) dapat memperlambat absorbsi glukosa dan tidak boleh digunakan pada kasus hipoglikemia yang darurat[13].

4. Glukosa 15 g (2 - 3 sendok makan) yang dilarutkan dalam air adalah terapi pilihan pada pasien dengan hipoglikemia yang masih sadar. 
a. 15 g glukosa (monosakarida) diperlukan dalam peningkatan glukosa darah sekitar 2,1 mmol/L dalam 20 menit dan dapat meredakan gejala bagi kebanyakan pasien [14]

b. 20 g glukosa diperlukan dalam peningkatan glukosa darah sekitar 3,6 mmol/L dalam 45 menit [15]

c. Susu dan jus jeruk lambat dalam menaikkan glukosa darah, namun dapat menghilangkan gejala [16]

5. Pasien dengan kontrol glikemik yang buruk dapat merasakan gejala hipoglikemia walaupun dengan kadar glukosa lebih 4,0 mmol/L. Tidak ada bukti yang menyatakan terjadi disfungsi kognitif. Maka dari itu, terapi hipoglikemia yang direkomendasikan adalah untuk meredakan gejala. Jadi, pasien yang mengalami hipoglikemia dengan kadar glukosa darah 4,0 mmol/ $\mathrm{L}$ dapat diterapi dengan snack karbohidrat, misalnya 1 buah pisang, atau 1 potong roti [7]

6. Anak - anak seringkali membutuhkan lebih sedikit $15 \mathrm{~g}$ karbohidrat untuk mengkoreksi kadar glukosa darah; bayi: 6 membutuhkan g; balita membutuhkan 8 g; dan anak kecil kemungkinan membutuhkan 10 g [13]

7. Pemeriksaan glukosa darah harus dilakukan setelah 15 menit setelah pemberian terapi. Ulangi langkah terapi hingga glukosa darah mencapai setidaknya 70 $\mathrm{mg} / \mathrm{dl}[5,13]$

8. Setelah kadar glukosa darah kembali normal, pasien diminta untuk makan atau mengkonsumsi snack untuk mencegah berulangnya hipoglikemia $[5,13]$

\subsubsection{Terapi Hipoglikemia Berat}

1. Glukagon merupakan hormon yang disekresi pankreas untuk menstimulasi hepar agar mengeluarkan glukosa yang tersimpan ke aliran darah. Injeksi glukagon dapat diberikan pada pasien DM dengan kadar glukosa darah yang terlalu rendah untuk diterapi dengan intake glukosa [13]

2. Jika didapat gejala neuroglikopenia, berikan dekstrosa $20 \%$ sebanyak 50 cc (jika kadar glukosa belum naik signifikan, diberikan dekstrosa $40 \%$ sebanyak $25 \mathrm{cc}$ ), diikuti dengan infus D5\% atau 10\% [5]

3. Periksa glukosa darah 15 menit setelah pemberian parenteral. Bila kadar glukosa darah belum mencapai target, dapat diberikan ulang dekstrosa 20\% [5]

4. Selanjutnya lakukan monitoring glukosa darah setiap 1 - 2 jam kalau masih terjadi hipoglikemia berulang. Pemberian dekstrosa 20\% dapat diulang. [5] 


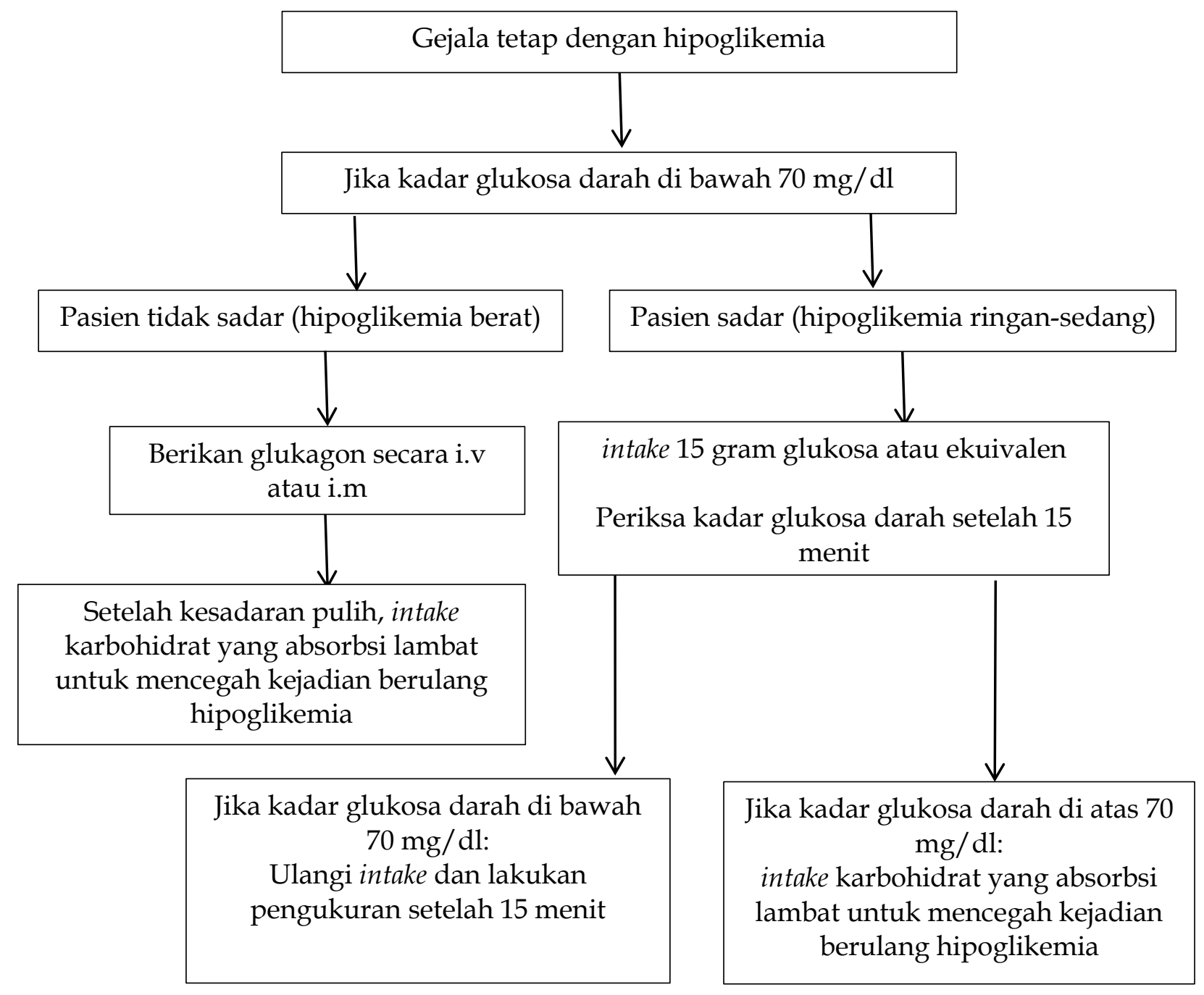

Gambar 1. Algoritme terapi hipoglikemia [10]

\subsection{Edukasi Pasien terhadap Hipoglikemia}

Masih sedikit penelitian yang meneliti edukasi managemen mandiri terhadap insiden dan pencegahan hipoglikemia. Namun, terdapat bukti yang kuatbahwa edukasi DM dapat meningkatkan luaran pasien. Menurut Seaquist et al [3], edukasi pasien terhadap hipoglikemia yang dapat diberikan, antara lain:

1. Dalam rencana edukasi, seseorang dengan DM maupun keluarganya harus mengetahui gejala hipoglikemia dan dapat mengatasi episodehipoglikemia dengan tepat, baik dengan glukosa oral maupun glukagon.

2. Faktor risiko hipoglikemia harus didiskusikan secara rutin kepada pasien yang mendapat terapi DM menggunakan insulin, obat sulfonilurea/glinid, khususnya kepada pasien yang memiliki riwayat hipoglikemia.

3. Pasien dengan DM diharapkan mengetahui makanan yang mengandung karbohidrat dan paham peran karbohidrat terhadap glukosa darah.

4. Untuk menghindari hipoglikemia, pasien dengan terapi kerja lama sekretagog dan insulin dosis tetap direkomendasikan agar membuat rencana makan yang tepat. 
5. Pasien dengan terapi insulin lainnya harus mengetahui bahwa injeksi prandial harus disertai dengan makan. Ketidakseimbangan pola makan dan injeksi insulin dapat menyebabkan fluktuasi dalam glukosa darah.

6. Pasien yang memiliki riwayat hipoglikemia dengan adanya terapi ADO harus diinstruksikan untuk selalu membawa karbohidrat agar dapat mengatasi hipoglikemia yang mungkin terjadi.

7. Aktivitas fisik meningkatkan pengunaan glukosa yang dapat meningkatkan risiko hipoglikemia. Faktor risiko hipoglikemia termasuk durasi olahraga, intensitas olahraga, ketidakcukupan suplai energi. Hipoglikemia karena olahraga dapat dihindari dan diminimalisir dengan memakan snack yang dengan mudah diserap tubuh.

\subsection{Monitoring Glukosa Darah}

Monitoring glukosa darah perlu dilakukan untuk mencegah risiko hipoglikemia. Pasien yang diterapi dengan insulin, sulfonilurea/ glinid dianjurkan untuk mengecek glukosa darah kapanpun merasa adanya gejala hipoglikemia. Hal ini dilakukan untuk mengkonfirmasi bahwa pasien harus mengkonsumsi karbohidrat untuk mengkoreksi level glukosa darah yang rendah [3]. Upaya PGDM dapat membantu meningkatkan kontrol glikemik pada pasien DM. Menurut Czupryniak et al [17], terdapat penurunan kejadian hipoglikemia dengan adanya upaya PGDM.

\section{Kesimpulan}

Hipoglikemia dapat dialami baik oleh pasien DM tipe 1 maupun pasien DM tipe 2. Hipoglikemia dapat terjadi secara akut, tiba-tiba dan dapat mengancam nyawa. Maka dari itu, pengetahuan tentang hipoglikemia, baik terhadap pencegahan, terapi dan monitoring harus diperhatikan jika terjadi hipoglikemia.

\section{Referensi}

[1]. International Diabetes Federation (IDF).2015.IDF Diabetes Atlas Seventh Edition. Brussels, Belgium: International Diabetes Federation.

[2]. PERKENI (Persatuan Endokrinologi Indonesia) ${ }^{b}$ 2015. Panduan Penatalaksanaan DM Tipe 2 pada Individu Dewasa di Bulan Ramadan. Jakarta: PB. Perkeni

[3]. Seaquist ER., Anderson J., Childs B., Cryer P., Dagogo-Jack S., Fish L, Heller SR., Rodriguez H., Rosenzweig J., Vigersky R.Hypoglycemia and Diabetes: A Report

of a Workgroup of the American Diabetes Association and The Endocrine Society Diabetes Care May 2013, 36 (5) 1384-1395; DOI: 10.2337/dc12-2480

[4]. PERKENI (Persatuan Endokrinologi Indonesia)a. 2015. Konsensus Pengelolaan dan Pencegahan Diabetes Melitus Tipe 2 di Indonesia 2015. Jakarta: PB. Perkeni

[5]. Yale, JF., Paty, B., Senior, PA. 2018 Clinical Practice Guidelines Hypoglycemia Diabetes Canada Clinical Practice Guidelines Expert Committee. Can J Diabetes 42: S104-S108

[6]. Cryer, P. E., Davis, S. N., \& Shamoon, H. (2003). Hypoglycemia in diabetes. Diabetes care, 26(6), 1902-1912 
[7]. Joint British Diabetes Societies - For Inpatient Care (JBDS-IP). 2018. The Hospital Management of Hypoglycaemia in Adults with Diabetes Mellitus 3rd edition. UK: Norfolk and Norwich University Hospitals NHS Foundation Trust.

[8]. Cryer PE.2008. The Barrier of Hypoglycemia in Diabetes. DIABETES, VOL. 57: 3169-3176

[9]. Inkster, B. \& Frier, B. M. 2012. The effects of acute hypoglycaemia on cognitive function in type 1 diabetes. The British Journal of Diabetes \& Vascular Disease, 12, 221-226.

[10]. Paluchamy,T. (2019). Hypoglycemia: Essential Clinical Guidelines, Blood Glucose Levels, Leszek Szablewski, IntechOpen, DOI: 10.5772/intechopen.86994 Available from: https://www.intechopen.com/books/blood-glucoselevels/hypoglycemia-essential-clinical-guidelines

[11]. Williams, S. A., Shi, L., Brenneman, S. K., Johnson, J. C., Wegner, J. C., \& onseca, V. (2012). The burden of hypoglycemia on healthcare utilization, costs, and quality of life among type 2 diabetes mellitus patients. Journal of Diabetes and its Complications, 26(5), 399-406.

[12]. Brown, S. H. M., \& Abdelhafiz, A. H. (2010). Hypoglycemia, intensive glycemic control and diabetes care in care home residents with type 2 diabetes. Aging Health, 6(1), 31-40.

[13]. American Diabetes Association (ADA). Hypoglycemia (Low Blood Sugar). (11 Juli 2020). Citing Internet Source URL https://www.diabetes.org/diabetes/medication-management/bloodglucose-testing-and-control/hypoglycemia

[14]. Slama G, Traynard PY, Desplanque N, et al. (1990). The search for an optimized treatment of hypoglycemia. carbohydrates in tablets, solutin, or gel for the correction of insulin reactions. Arch Intern Med.150:589-93

[15]. Canadian Diabetes Association (CDA). (1991). The role of dietary sugars in diabetes mellitus. Beta Release 15:117-23

[16]. Brodows RG, Williams C, Amatruda JM. (1984). Treatment of insulin reactions in diabetics. JAMA 252:3378-81

[17]. Czupryniak, L, Barkai, L, Bolgarska, S, Bronisz, A, Broz, J, Cypryk, K, Honka, M, Janez, A, Krnic, M, Lalic, N, Martinka, E, Rahelic, D, Roman, G, Tankova, T, Varkonyi, T, Wolnik, B, \& Zherdova, N. (2014). Self-monitoring of blood glucose in diabetes: from evidence to clinical reality in Central and Eastern Europe-recommendations from the International Central-Eastern European expert group. Diabetes Technol Ther, 16(7), 460-475. 